\title{
ABORDĂRI CONCEPTUALE ALE CONTEXTULUI SOCIAL ÎN EXPLICAREA COMPORTAMENTULUI DE SĂNĂTATE
}

\author{
Mariana CRÎŞMARU ${ }^{\circledR}$, drd., cercetător științific, \\ Centrul de Cercetări Demografice al INCE, Republica Moldova
}

DOI: https://doi.org/10.36004/nier.cdr.2019.14-12 Jel Classification: I12, I14.

Articolul prezintă o analiză a abordărilor conceptuale ale contextului social pentru a ințelege multiplele influențe sociale, organizaționale, istorice, politice și culturale asupra comportamentului de sănătate. Contextul social este definit ca fiind acele forțe socioculturale care modelează experiențele cotidiene ale oamenilor și care afectează în mod direct și indirect sănătatea și comportamentul de sănătate. In lucrare sunt descrise modelele şi teoriile sociale în domeniul sănătătii în baza concepțiilor lui Bourdieu și Giddens cu privire la "practicile sociale" și evidențiată aplicabilitatea lor în explicarea unor comportamente de sănătate. Aceste abordări reliefează o perspectivă mai profundă a studierii relației dintre factorii structurali, viața de zi cu zi, sănătate și comportament de sănătate.

Cuvinte-cheie: context social, factori structurali, comportament de sănătate, habitus, Teoria Practicii Sociale

The article presents an analysis of the conceptual approaches of social context in order to understand the multiple social, organizational, historical, political and cultural influences on health behavior. Social context is defined as those socio-cultural forces that shape people's daily experiences and which directly and indirectly affect health and health behavior. In the paper are described social models and theories in the health based on Bourdieu and Giddens conceptions of "social practices"and emphasized their applicability in explaining certain health behavior. These approaches highlight a deeper prospect for studying the relationship between structural factors, daily life, health and health behavior.

Key words: social context, structural factors, health behaviour, habitus, Theory of Social Practice

Argumentare. Importanța integrării contextului social în cercetările privind comportamentele relaţionate cu sănătatea este pe larg recunoscută şi conceptualizată, iar constatările şi recomandările acestor studii sunt cruciale pentru elaborarea şi implementarea unor programe şi politici eficiente de promovare şi educaţie pentru sănătate.

Reconsiderarea rolului contextului social în sănătatea publică se datorează, în special, criticilor aduse teoriilor individualiste şi cognitiv-comportamentale, care, în cea mai mare parte, nu i-au în considerare factorii structurali ai determinării stării sănătății. Comportamentele de sănătate sunt analizate în cadrul acestor teorii în afara contextului social [4], izolat de alți indivizi și privite drept practici fără semnificație socială [1].

Se remarcă, că teoriile psihologice au dominat cercetările în domeniul sănătăţii publice pe parcursul ultimelor decenii reușind să înregistreze anumite progrese în înțelegerea proceselor cognitive şi atitudinal-motivaționale, deşi s-au concentrat excesiv asupra trăsăturilor de personalitate sau alegerii raționale a individului[7]. Astfel, Modelul Convingerilor despre Sănătate (Rosenstock, 1966) explica modul de formare a comportamentelor relaţionate cu sănătatea prin prisma a două componente: percepţia amenințării bolii sau a comportamentului cu risc pentru sănătate şi costurile şi beneficiile comportamentului. Teoria Comportamentului Planificat (Azjen 1985, 1988, apud Berry, 2004) corelează credinţele despre comportamentele importante pentru

\footnotetext{
๑ Mariana Crîșmaru, mariana_mascautan@yahoo.com
} 
sănătate direct cu comportamentul şi propune conceptualizarea intenţiilor ca planuri de acţiune pentru atingerea scopurilor. Teoria Autoeficacităţii (Bandura 1982) se referă la convingerea unei persoane în capacităţile sale de a-şi mobiliza resursele cognitive şi motivaţionale necesare adoptării unor comportamente.

În cadrul acestor teorii, influențele sociale, organizaționale, istorice, politice și culturale asupra comportamentului individual sunt, în cel mai bun caz, prezentate drept variabile auxiliare sau proxy, acceptate numai în măsura în care influențează credinţele, atitudinile şi convingerile individului în materie de sănătate. Chiar dacă impactul unor astfel de influențe este recunoscut, acestea sunt prezentate ca unidirecționale, individul fiind destinatarul sau obiectul forțelor externe neschimbate.

Sub aspectele enumerate mai sus, dar și odată cu depășirea abordării individualiste a comportamentului de sănătate, cercetătorii din domeniul ştiinţelor sociale au generat modele care tind să demonstreze modalităţile inextricabile prin care contextul social, într-o varietate de forme, este parte integrantă şi influențează comportamentul de sănătate, este mecanism de schimbare, cât și de mediere a comportamentului[11], de re-definire a contextului social ca regulator de risc[5]. Prin urmare, contextul social deschide noi oportunități pentru o înțelegere mai profundă a comportamentelor relaţionate cu sănătatea, precum și a inegalităților în materie de sănătate.

Definiţii şi abordări conceptuale. Contextul social este definit ca fiind acele forțe socioculturale care modelează viața de zi cu zi a indivizilor și le afectează direct sau indirect sănătatea și comportamentul de sănătate[9]. Aceste forțe includ structuri și procese istorice, politice, juridice (de exemplu acte normative, politici publice etc.), organizații și instituții (de exemplu școli, instituții medicale, comunitate), precum și traiectorii individuale și personale (de exemplu familie, relaţii interpersonale). Se remarcă, relaţia dintre individ şi contextul social este una deosebit de complexă, multidirecțională, co-constitutivă de aceste forţe, în continuă formare şi care afectează indivizii fără ca aceștia să fie conștienți de acest fapt.

Interesul ştiinţelor sociale, în special al sociologiei, pentru factorii comportamentali nu este unul nou, aceste subiecte au fost în centrul dezbaterilor cercetătorilor care au fost preocupaţi preponderent de identificarea condiţiilor şi circumstanţelor favorizante menţinerii sănătăţii, cât și a condiţiilor favorizante apariţiei bolilor, cu scopul de a propune explicaţii care ar ajuta oamenii să-şi reorienteze comportamentele. În acest context, E. Durkheim a investigat dependența comportamentului uman (cu referință la suicid) față de procesele sociale M. Weber a pus bazele studierii stilului de viață, iar T. Parsons a acordat o atenţie deosebită interpretării rolului medicinii în societate prin analizarea comportamentului rolului de medic şi pacient.

O mare parte din teoriile moderne asupra comportamentelor / stilurilor de viaţă se bazează pe lucrările sociologilor clasici. Astfel, Teoria Modernă a Stilului de Viață a fost dezvoltată de Cockerham [2] și reflectă conceptul fundamental al stilului de viață al sociologului german M. Weber (1978), ce se referea la oportunităţi (life chances) pe care oamenii le au în alegerea unui anumit stil de viaţă şi opţiuni (life choices) care reprezintă probabilitatea realizării acestor opţiuni, luând în consideraţie condiţiile structurale necesare. Potrivit lui Cockerham, oportunitățile indivizilor sunt influențate de circumstanțele materiale și de clasa socială: gradul de stratificare socială în funcție de vârstă, sex, rasă / etnie; relații sociale colective bazate pe norme, idealuri comune. Toate aceste variabile descriu un context social în care are loc procesul de socializare și care afectează experiențele trăite de-a lungul vieții, influențând și capacitatea indivizilor de a face alegeri specifice în materie de sănătate.

La rândul său, o bună parte din modele şi teoriile sociale în domeniul sănătăţii se bazează pe conceptualizările lui Bourdieu (1990a) și Giddens (1984) ale practicii sociale, care au drept scop o înţelegere mai profundă a relaţiei dintre factorii structurali, viaţa de zi cu zi, sănătate și comportament de sănătate. Bourdieu a introdus conceptul de ,, habitus”, pe care îl definea ca acea structură de practici și dispoziții, în funcție de contextualitatea culturală, prin care se formează un stil de viață. Sociologul considera că intenţiile conştinete şi deliberate sunt explicaţii, necesare dar 
insuficiente pentru a explica comportamentul. Habitus-ul, în concepţia lui, denotă structuri puternice, acumulate pe parcursul istoriei, care au un rol generator și unificator în raport cu viziunea asupra lumii cu manifestările comportamentale ale individului (Bourdieu, 1978).

În viziunea lui Giddens (2000), comportamentul individului, stilul de viaţă al familiei este modelat de factori precum presiunea grupului, modelele de rol acumulate sau învățate, cât și contextele sociale și economice. Potrivit sociologului, odată ce individul face parte dintr-un anumit grup sau categorie socială, acesta va accepta stilul de viață caracteristic acestui grup, atât în ceea ce privește satisfacerea necesităților, cât și îi va modela identitatea individuală.

Ideile lui Giddens și Bourdieu au fost dezvoltate în cadrul Teoriei Practcii Sociale [13]. Conceptul de practică socială este definit exclusiv în cadrul contextului social și cultural - adică al structurilor şi modelelor mai largi ale vieții sociale[14]. Acest concept reflectă faptul că nici un comportament nu poate fi privit izolat de contextul său imediat și mai larg, şi, totodată, indică asupra faptului că un comportament nu este doar un produs al contextului definit, dar şi contribuie la modificarea acestuia. Comportamentul, în acest caz, constituie şi este constituit în acelaşi timp de regulile, relațiile, așteptările și resursele structurilor sociale.

Teoria Practicii Sociale are la bază trei elemente de bază, şi anume:

- Mijloace fizice / materiale: obiectele, infrastructură care permit sau facilitează anumite activități pentru a fi realizate în moduri specifice.

- Sensuri: imagini, interpretări sau concepte asociate cu activități care determină cum și când ar putea fi efectuate.

- Proceduri: aptitudini, know-how sau competențe care permit sau duc la activităţi de desfășurare în anumite moduri.

Se remarcă faptul că variaţiile moderne ale acestei teorii au exclus unele limitări identificate la prima etapă de elaborare a concepțiilor privind comportamentele de sănătate. În primul rând, practicile sociale sunt recunoscute actualmente drept entităţi discrete cu istoricul şi traiectoria proprie și se disting momentele de inițiere a unei practici / și de performanță, continuare [13] de către „purtătorii” individuali (,carriers”) [10]. Astfel, unitatea de analiză și monitorizare a schimbărilor devin practicile sociale şi nu comportamentul individual.

În al doilea rând, luând în consideraţie că lumea socială este tot mai dependentă de dezvoltarea tehnologică, în care există o diversitate de gadget-uri, programe computerizate etc. care pot avea atât un impact pozitiv, cât şi negativ asupra sănătății și comportamentului de sănătate, acestora li s-a acordat statutul de elemente active care constituie şi influenţează comportamentele indivizilor [10].

Aplicabilitatea teoriilor sociale. Teoria Practicii Sociale este tot mai des utilizată în analiza comportamentului uman, inclusiv în cel relaţionat cu sănătatea. Aplicarea acestei abordări în cercetările asupra comportamentului de sănătate înseamnă a schimba focusarea de la indivizi și comportamentele acestora către practica socială (de exemplu consumul de alcool, care va servi drept unitate de analiză). Studierea modului în care apar practicile de consum de alcool, cum se reproduc, persistă și dispar în timp, cum se răspândesc în rândul populaţiei prin intermediul rețelelor locale sau sociale și cum corelează cu alte activități din viața cotidiană va oferi informație nouă despre cum, de ce, unde, când și cu cine se consumă[8].

Operaționalizarea acestei abordări prin prisma elementelor constitutive în cadrul Teoriei Practicii Sociale aplicat în cazul consumului de alcool:

- Materiale (echipamente / resurse / infrastructură): de exemplu băuturi alcoolice, magazine specializate, localuri de odihnă şi agrement etc.

- Semnificații simbolice: de exemplu relaxare, apartenență la un anumit grup, prietenie etc.

- Competențe (proceduri / abilităţi): de exemplu conștientizarea ritualurilor de consum specifice anumitei culturii, cunoașterea maximului admis de alcool în sânge, etc.

Teoria Practicii Sociale a fost folosită pentru a explica creșterea mortalității în grupuri specifice de populaţie din Rusia. S-a argumentat că un habitus sau o practică care este constantă, 
cum ar fi consumul abuziv de alcool, poate deveni o normalitate pentru multe persoane, în special pentru bărbați, și reprodusă de-a lungul timpului, atunci când este practicată în mod regulat. De asemenea, potrivit unor cercetători, în unele societăți lipsește sau este o stigmatizare socială scăzută pentru persoanele care consumă alcool în cantități mari. Deși se poate afirma cu certitudine că un astfel de habitus este nociv pentru sănătate, dispozițiile pe care le produce poate fi un stil de viață normativ pentru un anumit grup de persoane [6],[12].

Un studiu ${ }^{19}$ care a avut drept scop explorarea incidenței și determinarea factorilor individuali determinanți ai fumatului și consumului de alcool în rândul tinerilor din Moldova s-a axat pe integrarea Teoriei Practicii Sociale în explicarea adoptării acestor comportamente [3]. Potrivit rezultatelor acestui studiu, ratele de consum de tutun și alcool în rândul bărbaţilor sunt mult mai înalte comparativ cu ratele înregistrate în rândul femeilor. Totodată, conform analizei multivariate, sexul (masculin) și vârsta sunt factorii individuali determinanți pentru ambele practici comportamentale. Un alt predictor important l-a constituit nivelul de educație al tinerilor - tinerii cu un nivel de educație mai scăzut au o probabilitate mai mare să fumeze și să consume alcool. La rândul său, studiul a scos în evidență o puternică interdependență între aceste comportamente cu risc pentru sănătate.

Aplicând Teoria Practicii Sociale s-a argumentat că prevalența ridicată a fumatului și a consumului de alcool în rândul bărbaților reflectă o structură normativă pentru socializarea acestora. Aceste dispoziții normative, de exemplu consumul de alcool, devin interiorizate drept habitus-uri și pot fi reproduse de-a lungul generațiilor prin faptul că sunt acționate constant, după cum explică Bourdieu (1984). Chiar dacă se vorbește că o persoană are întotdeauna posibilitatea de alegere, normele de grup pot avea prioritate. Potrivit lui Bourdieu, indivizii pot avea control asupra anumitor alegeri în viața cotidiană, dar nu neapărat asupra condițiilor sociale și psihologice care canalizează acele alegeri într-o anumită direcție.

Concluzii. Integrarea contextului social în înțelegerea comportamentului de sănătate este deosebit de importantă şi tot mai des utilizată în cadrul cercetărilor din domeniul sănătăţii. Contextul social este constituit din diverse domenii care interacționează între ele, influențează individul și sunt influențate de către individ. Cea mai directă include interacțiunile familiale, relațiile și suportul comunitar (de exemplu, interacțiunile dintre prieteni, colegi și membri ai acelorași grupuri comunitare, cum ar fi organizațiile bisericești). Cadrul contextual al instituțiilor sau organizațiilor include structurarea accesului și a barierelor la asistența medicală și capacitatea de a mobiliza resurse pentru a obține ceea ce cineva are nevoie. Cadrul politic / istoric / legal include factori demografici, politici, economici, culturali și istorici la scară largă, legi (de exemplu, privind cetățenia), reglementări și politici.

Teoria care tot mai des este utilizată în explicarea comportamentului de sănătate este Teoria Practicii Sociale, care nu se focalizează asupra comportamentului individual, dar asupra practicii sociale, adică a performanțelor comportamentelor de rutină care sunt împărtășite de către membrii unui anumit grup. Se consideră că practicile construiesc și mențin sistemele dinamice complexe în care sunt localizate și explică stabilitatea și rezistența la schimbare în multe activități cotidiene.

\section{Bibliografie}

1. Burke Nancy J. et. all. Theorizing Social Context: Rethinking Behavioral Theory. Health Education \& Behavior, 2009, Vol 36, Issue 5_suppl., p. 55-70.

2. Cockerham W. C. Health lifestyle theory and the convergence of agency and structure. Journal of Health and Social Behavior, 2005, Vol. 46, Issue 1, p. 51-67.

3. Crîșmaru M. Social patterns of smoking and alcohol drinking among young people in Moldova. Economy and Sociology, 2019, nr. 1, p. 133-144.

\footnotetext{
${ }^{19}$ Studiul se bazează pe analiza secundară a datelor Sondajului Național al Tinerilor din Moldova în rândul populației de 14-29 ani (1112 respondenți) realizat în 2016 în cadrul proiectului de incluziune UE-OCDE şi Ministerul Educației, Culturii și Cercetării din Moldova.
} 
4. Frohlich K., Corin E., Potvin L. A theoretical proposal for the relationship between context and disease. Sociology of Health \& Illness, 2001, Vol. 23, nr. 6, p. 776-797. https://onlinelibrary.wiley.com/doi/epdf/10.1111/1467-9566.00275.

5. Glass T., McAtee M.J. Behavioral science at the crossroads in public health: Extending horizons, envisioning the future. Social Science \& Medicine, April 2006, Vol. 62, Issue $\quad 7, \quad$ p. 1650-1671. https://www.sciencedirect.com/science/article/abs/pii/S0277953605004624?via\%3Dihub.

6. Hinote Brian P. William C. Cockerham: The Contemporary Sociology of Health Lifestyles. The Palgrave Handbook of Social Theory in Health, Illness and Medicine (ed. Collyer F.), 2015, Chapter 30, p. 471-487. https://link.springer.com/chapter/10.1057/9781137355621_30.

7. Maller Cecily Jane. Understanding health through social practices: performance and materiality in everyday life. SCI Seminar Series, $1^{\text {st }}$ Septembrie 2014. https://www.slideshare.net/CecilyMaller/mallerunderstanding-health-through-social-practicesperformance-and-materiality-in-everyday-life.

8. Meier Petra Sylvia, Warde Alan. All drinking is not equal: how a social practice theory lens could enhance public health research on alcohol and other health behaviours. Addiction, 2018, 113(2), p. 206-213. Epub., 2017, July 11: http://eprints.whiterose.ac.uk/119056/8/Meier_et_al_social_practice_theory_and_drinking_FIN_cle an_copy.pdf.

9. Pasick R.J., Hiatt R.A., Paskett E.D. Lessons learned from community-based cancer screening intervention research. Cancer. 2004, Vol. 101, Issue 5, supplement, p. 1146-1164. https://www.academia.edu/19761437/Lessons_learned_from_community-

based_cancer_screening_intervention_research.

10. Reckwitz A. Toward a Theory of Social Practices: A Development in Culturalist Theorizing, European Journal of Social Theory, 2002, Vol. 5, Issue 2, p. 243-263. http://citeseerx.ist.psu.edu/viewdoc/download?doi=10.1.1.922.8711\&rep=rep1\&type=pdf.

11. Sorensen G., Emmons K., Hunt M.K., Barbeau E., Goldman R., Peterson K., Kuntz K., Stoddard A., Berkman L. Model for incorporating social context in health behaviour interventions: Applications for cancer prevention for working class, multiethnic populations. Preventive Medicine, 2003, Septembrie, Vol 37, issue 3, p. 188-197.

12. Wallace C. D. \& Haerpfer C. W. Living Conditions, Lifestyles and Health. Routledge, 2010.

13. Warde A. Consumption and Theories of Practice. Journal of Consumer Culture, 2005, Vol. 5, Issue 2, p. 131-153.

14. Williams S. Theorising class, health and lifestyles: Can Bourdieu help us? Sociology of Health \& Illness, 1995, Vol. 17, nr. 5, p. 577-604. https://onlinelibrary.wiley.com/doi/pdf/10.1111/1467-9566.ep10932093. 